\title{
Old Age Abuse
}

\section{A new perspective}

\section{Second edition}

\author{
Edited by \\ Meroyn Eastman \\ Social Services Department \\ Enfield, Middlesex, UK
}

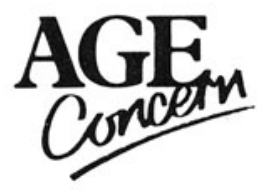

Co-published with Age Concern England

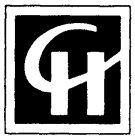

Springer-Science+Business Media, B.V. 
First edition 1984

Second edition 1994

(C) 1994 Springer Science+Business Media Dordrecht Originally published by Chapman \& Hall in 1994

Typeset in 10/12pt Palatino by Mews Photosetting, Beckenham, Kent

ISBN 978-1-56593-291-3

ISBN 978-1-4899-3077-4 (eBook)

DOI 10.1007/978-1-4899-3077-4

Apart from any fair dealing for the purposes of research or private study, or criticism or review, as permitted under the UK Copyright Designs and Patents Act, 1988, this publication may not be reproduced, stored, or transmitted, in any form or by any means, without the prior permission in writing of the publishers, or in the case of reprographic reproduction only in accordance with the terms of the licences issued by the Copyright Licensing Agency in the UK, or in accordance with the terms of licences issued by the appropriate Reproduction Rights Organization outside the UK. Enquiries concerning reproduction outside the terms stated here should be sent to the publishers at the London address printed on this page.

The publisher makes no representation, express or implied, with regard to the accuracy of the information contained in this book and cannot accept any legal responsibility or liability for any errors or omissions that may be made.

A catalogue record for this book is available from the British Library Library of Congress Catalog Card Number: 94-70927

Printed on permanent acid-free text paper, manufactured in accordance with ANSI/NISO Z39.48-1992 and ANSI/NISO Z39.48-1984 (Permanence of Paper). 
This book is dedicated to the memory of my father-in-law, Ted Levett, whom I miss greatly 
'... I pushed her down the stairs and killed her

Anonymous telephone call following item in

The Guardian, 17.3.82

'... I would honestly not have thought that I could ever have felt like I did, and still think "granny battering" is abhorrent. If there is an answer I hope society will find it quickly.'

Mrs N. (Gwent) 


\section{Contents}

List of contributors vii

Foreword ix

Sally Greengross

Preface xiii

\section{Part One The Nature of Abuse}

1 Introduction: the issues, practice and policy 3 Claudine McCreadie

2 The victims: older people and their carers in a domestic setting

Meroyn Eastman

3 Prevalence and prevention of abuse Ann Homer

4 Caring for carers: understanding the process that leads to abuse

Elizabeth Hocking

\section{Part Two Older People, Home and Away}

5 Dependency or interdependency? Is the concept of 'dependent-abuse' helpful?

Mervyn Eastman

6 Dependence, power and violation: gender issues in abuse of elderly people by formal carers Raymond Jack 
7 Physical abuse in homes and hospitals Chris Gilleard

\section{Part Three Dealing with Old Age Abuse}

8 Clinical diagnosis and treatment Gerald Bennett

9 Social work practice in dealing with abuse Jacki Pritchard

10 Considerations for practice Bridget Penhale

\section{Part Four Aspects of Abuse}

11 Racial aspects of elder abuse James George

12 Homicide in elderly couples

Bernard Knight

13 Social work and old age abuse: laying down the law

Phil Slater

14 Lifting the lid on elder abuse: questions and doubts

Jim Traynor

\section{Part Five Training Issues}

15 Elder abuse and neglect: developing training programmes

Simon Biggs and Chris Phillipson

16 Perspectives in training: assessment and intervention issues in old age abuse Fiona Goudie and Drew Alcott

Appendix A summary and commentary on No Longer Afraid 


\section{Contributors}

Drew Alcott Chartered Clinical Psychologist, Unsted Park Rehabilitation Hospital, Surrey.

Dr Gerald Bennett Senior Lecturer in Health Care of the Elderly, London Hospital Medical College; Honorary Consultant, Royal Hopsital Trust; Consultant in Care of the Elderly, City and East London Family and Community Health Services.

Dr Simon Biggs Programme Co-ordinator, Central Council for Education and Training in Social Work, London.

Mervyn Eastman Deputy Director of Social Services, London Borough of Enfield, Middlesex.

Dr James George Consultant in Medicine for the Elderly, Cumberland Infirmary, Carlisle.

Dr Chris Gilleard Top Grade Clinical Psychologist, Springfield University Hospital, and Senior Lecturer in the Psychology of Old Age, St George's Hospital Medical School, London.

Fiona Goudie Chartered Clinical Psychologist, Nether Edge Hospital, Sheffield.

Dr Elizabeth Hocking Consultant Geriatrician (retired), St Margaret's Hospital (Skatton), Wiltshire.

Dr Ann Homer Consultant Physician, Department of Medicine for the Elderly, Edgware General Hospital, Middlesex.

Dr Raymond Jack Director of Post-Qualifying Studies in Social Work, Anglia Polytechnic University, Cambridge. 
Professor Bernard Knight Professor of Forensic Pathology, Institute of Pathology, Royal Infirmary, Cardiff.

Claudine McCreadie Age Concern Institute of Gerontology, King's College London.

Bridget Penhale Social Work Team Leader, St Michael's Hospital, Norfolk.

Chris Phillipson Professor in Applied Social Studies and Social Gerontology, University of Keele, Staffordshire.

Jacki Pritchard Locality Manager in the Sheffield Family and Community Services Department, Sheffield.

Dr Phil Slater Principal Lecturer in Social Work, Middlesex University and Enfield Social Services Department, Middlesex.

Jim Traynor Community Care Manager, Leeds City Council, Leeds. 


\section{Foreword}

Age Concern always seeks to be at the forefront in raising issues of importance as part of our continuing fight to improve the quality of life of older people. To this end we are privileged in being able to draw on the skills of people with the commitment, expertise and enthusiasm to press for much needed change. When, some years ago, we published a book by Mervyn Eastman on old age abuse, the subject was largely unrecognized. He played a pioneering role in drawing attention to this difficult and sensitive topic, classifying the various types of abuse, analysing their causes, their tragic effects and the different contexts in which they were likely to occur.

Earlier, when I joined Age Concern, I had been struck by the paucity of knowledge of old age abuse. My previous work with children and young people provided me with stark reminders of how much more developed both policy and practice were in dealing with the abuse of children. Even in that field there was still much to learn, and subsequent legislation, policy guidelines and codes of practice have taken us further down the road by constructing clear lines of accountability and by protecting and representing children at risk, by helping potential abusers and developing practice that avoids punishing victims through removing them from their homes. Such progress was made from a position of strength when compared with the situation of elderly people, whose vulnerability to abuse was often denied, misunderstood or discounted. In a subsequent book, published in 1986, Age Concern drew up a range of recommendations for changes in the law. Some of those appear to have influenced the comprehensive proposals recently drawn up by the Law Commission. Recent guidelines 
produced by the Social Services Inspectorate will also, hopefully, improve practice in this delicate and sensitive area of work.

Another welcome initiative is the recent establishment of a new specialist organization, Action on Elder Abuse, which Age Concern has been able to support in its initial stages of development. Through it, we hope that people in different disciplines and professions will be able to come together, drawn by their determination to eradicate a most pernicious and tragic form of ill treatment affecting one of the most vulnerable groups in our society.

There has certainly been some progress since the early days when our attention was first drawn to old age abuse, and this new book, with which Age Concern England is delighted to be associated, is both a major step forward in its own right and a pointer to the future. Through it we can better appreciate the complicated relationships from which explosive situations may well erupt. We should be better equipped to prevent abuse by understanding the underlying power relationships frequently involved and the dilemmas and stresses affecting professional care staff and carers alike.

The book underlines the need for training to help us grasp this difficult issue with sensitivity and strength, so that if we cannot totally eradicate old age abuse we can at least hope to reduce its occurrence and mitigate some of its worst effects. Some questions, however, remain. How much is this form of abuse a human response by a tiny minority to society's neglect and to the fact that collectively we hold an unrealistic assumption about people's capacity to care, whether for a relative or for a patient or client, with little support, for a period that may extend to many years? Most people enter a caring relationship through devotion and love, but some will face an intractable situation in which individual choice, dignity and a degree of autonomy for vulnerable elderly people or those who care for them are unrealistic options talked about by people who often have little understanding of what is really involved.

Through all these years Mervyn Eastman's commitment to this subject has remained unparalleled. In this book he has been able to complement his own very particular insights with those of experts in many areas of specialist interest. It is most fitting that he has taken on this role in a publication that marks 
an important step in our quest to improve the lives of the many people who need our help and whose voices must be heard. They are, by definition, frail and extremely vulnerable. It is easy to ignore them. This book is important as one way of ensuring that they are not ignored and that their voice is heard before it is too late.

\author{
Sally Greengross \\ Director \\ Age Concern England
}




\section{Preface}

Much has changed since the mid-1980s in how we view violence against older people by family members, and new 'experts' have come to the fore. Baker, Bursten and myself have been joined, even eclipsed, by the likes of Bennett, McCreadie, Homer and Pritchard, and this is how it should be. Their contributions to the field since the publication of the first edition of this book, Old Age Abuse, in 1984 have enhanced our knowledge, broadened our understanding and raised more questions.

It is therefore the intention of this book to provide an overview of the current thinking on the causes and consequences of, and possible interventions in, old age abuse by some of those who are committed to increasing our awareness of the problem.

Two issues in particular have grown in importance for me since 1984. Firstly, is 'dependency' a factor in abuse or simply a function of the sampling done by researchers? And second is the matter of violence in the residential setting.

With regard to the former, I am still of a mind to consider dependency (whatever this may mean) to be a key factor. But dependency cannot be separated from 'power'! The use and abuse of power in relationships, whether intimate or casual, formal or informal, paid or unpaid, perhaps offers a key to increasing our understanding. This area needs further work and will, perhaps take several years: even in child protection work we skirt the edges of the pool - or is it a sea - in coming to terms with 'dependency' and the power of an adult over the life of a child.

It is a matter of deep regret to me that I have paid so little attention over the past decade or so to the second important 
issue, that of the links between elder abuse in the domestic setting and institutional abuse. From Barbara Robb's Sans Everything published in 1967 (Thomas Nelson \& Sons) to the Inquiry into Nye Bevan Lodge (Gibbs, Evans and Rodway, see References to Chapter 5) in 1987 and beyond, one is forced to ask: what are the differences between an adult daughter or son caught in the carer's trap and a care assistant or officer caught in the mindless routine of residential provision?

Taking the concept of power, I have often been asked by audiences of professional workers to comment on the notion that older people contribute to their own abuse. While I accept that the behaviour of some older people does act as a trigger for their carers to abuse, this should not justify, but rather explain, the reason(s) people abuse. Whatever the causal factors, to harm another person, especially when vulnerable, remains an offence both in legal and human rights terms. 'They asked for it, didn't they?' was a prevalent notion in the late 1970s. It is still around today, and can easily lead to the further disempowerment of older people. Victims can easily be turned into 'persecutors' especially if the power rests with those who care for vulnerable adults.

I hope that this edition will plug many of the unintentional gaps of the 1984 book, although I am aware that as some gaps are filled, others open up. No reader should approach this edition expecting the definitive update on abuse. It is not a handbook, a study text or a manual, it is simply reflections brought together in the form of contributions from leading experts. It is intended to complement the growing literature on elder abuse, an issue that I am convinced is set to explode over the next five or so years.

One significant gap, soon to be filled by the work of Malcolm Holt, a social worker with Northumberland social services, is in the area of elder sexual abuse in the UK. I recently met Malcolm at a conference where he outlined his findings. These were published in 1993 by King's College Age Concern Institute of Gerontology as part of the Ageing Update Conference proceedings - Elder Abuse: New Findings and Policy Guidelines.

Sexual abuse, he argues, needs to be specifically included in definitions of elder abuse and in practice guidelines. His work is extremely challenging and I am convinced that, as a result, he will find many enemies within social work, research 
result, he will find many enemies within social work, research and management as he bravely seeks to break through what is, perhaps, the final taboo. I was unable to invite him to contribute, and hope this acknowledgement will in some way give Malcolm support and encouragement in his pioneering work so reminiscent of my own experiences between 1980 and the publication in 1984 of Old Age Abuse.

There is inevitably some overlap in material between chapters, but I follow Jordon Kosberg's reasoning in Abuse and Maltreatment of the Elderly (John Wright, PSG Inc., 1985), that such overlapping 'underscores certain commonalities'. I have, nevertheless, attempted to edit out repetitiveness so as not to bore readers who prefer to read the book as a whole, rather than dipping in and selecting areas of particular interest.

The book is divided into sections. Part One examines the nature of abuse and Claudine McCreadie has given an excellent general introduction to the issues, practice and policy. Dr Ann Homer examines the prevention of abuse by drawing on a study she conducted in south London during the late 1980s, and Dr Elizabeth Hocking, a longstanding friend and co-worker of mine, considers the process that leads to abuse from the point of view of the carers.

Part Two continues the carers' theme, firstly by examining the notion of 'dependant abuse'. Dr Ray Jack then looks at dependence, power and violation as 'the currency of relationships rather than the property of individuals' and Dr Chris Gilleard looks at residential and hospital settings. The two thus address a significant gap in my first publication.

Dr Gerald Bennett begins Part Three, which looks at dealing with old age abuse, with a chapter on clinical diagnosis and treatment. Dr Bennett has become one of the UK's most fervent and prolific contributors to our understanding of old age abuse, and I am proud to have his name associated with this publication.

Jacki Pritchard is yet another whose name I am happy to include, and her chapter considers how local authority social services departments are currently addressing the issue of old age abuse, their methods and practices. Bridget Penhale continues the consideration of practice, examining the similarities and differences between old age abuse and other forms of domestic violence. 
I make no apology for the emphasis in this section of the book on social work practice, as it continues to play a central and crucial role in assessment and prevention as we move towards the full implementation of the NHS and Community Care Act, 1990.

Part Four looks at various aspects of abuse. First, Dr James George considers the racial and ethnic dimension (a chapter which proved extremely difficult to obtain a contribution for) and then follows Professor Bernard Knight's fascinating, but disturbing, work on geriatric homicide. He writes, 'the killing of an elderly person by his or her spouse should not be too unexpected ...' ' and gives the reader a valuable insight into an often neglected aspect of elder abuse.

Part Four concludes with Jim Traynor 'Lifting the lid on elder abuse'. Traynor and I have been sparring partners for a number of years: I find his scepticism as disturbing as he finds my compulsion! Traynor offers readers a haven of balance.

Training issues provide the focus for the final section of the book. Dr Simon Biggs and Professor Chris Phillipson concentrate on the development of training programmes and Fiona Goudie and Drew Alcott consider assessment and intervention from a training perspective. Since we are moving increasingly towards multi-agency needs assessment and joint training initiatives, their contribution is greatly appreciated.

By having this book 'topped' and 'tailed' by McCreadie and Dr Biggs and Professor Phillipson, I consider I have brought together writers whose combined scholarship and experience (added to that of all the contributors who so willingly accepted the challenge and gave their time) make this book clear, understandable and, above all, unequalled and unique in the literature of old age abuse.

As the editor of this book I would particularly like to acknowledge the contribution of Sally Greengross. She supported and encouraged my interest in old age abuse when I was a young social worker and as I now enter middle-age she continues to pioneer this area of investigation and research. Her own contribution cannot be underestimated and her commitment knows no limits.

Chapman \& Hall have, over nearly two years, offered encouragement, support, skill and determination. The patience of Lisa Fraley (editor) was remarkable and she was a constant 
source of help and support as I doubted my ability to draw the book together. I am also grateful to Lynne Maddock (subeditor) whose work was always underpinned by professionalism and determination. My thanks also to Chapman \& Hall's production department, and last, but by no means least, my thanks go to Fiona Toms (copy-editor), who demonstrated a skill and ability that were awesome. Without doubt, Fiona turned a rough and contradictory manuscript into a product of good quality. To her I owe a debt I can never repay.

Finally, attempting to produce a book that is up-to-date is like trying to catch a moving train. By the time it is published, well-informed readers may complain that it does not include the latest findings. This, I argue, cannot be avoided, and I would simply ask well-informed readers to bear in mind that their knowledge surpasses that of the majority, who will hopefully value the contribution this publication makes to understanding elder abuse.

The mission of this book is to encourage the opening of closed doors; to encourage care professionals and their managers to consider abuse of older people to be an aspect of their work that can no longer be denied or ignored.

Meroyn Eastman July 1993 